\title{
Çocuk Hastalarda Parainfluenza Nedenli Alt Solunum Yolu İnfeksiyonlarının Araştırılması
}

\author{
Investigation of Parainfluenza Virus Caused Lower \\ Respiratory Tract Infections in Pediatric Patients
}

Aysun Görkem ${ }^{1}$,

Ayşe Rüveyda Uğur ${ }^{1}$,

Bahadır Feyzioğlư ${ }^{1}$,

Mehmet Özdemir ${ }^{1}$,

Mahmut Baykan²,

${ }^{1}$ Necmettin Erbakan Üniversitesi, Meram Tıp Fakültesi, Mikrobiyoloji Anabilim Dalı, Viroloji Bilim Dalı, Konya, Türkiye

${ }^{2}$ Necmettin Erbakan Üniversitesi, Meram Tıp Fakültesi, Mikrobiyoloji Anabilim Dalı, Konya Türkiye

Geliş Tarihi/Received: 5 Kasım 2018 Kabul Tarihi/Accepted: 15 Ağustos 2019

Yazışma Adresi: Aysun Görkem, Necmettin Erbakan Üniversitesi, Meram Tıp Fakültesi, Mikrobiyoloji Anabilim Dalı, Konya, Türkiye e-posta: dr.aysunk@hotmail.com

\section{ORCID}

Aysun Görkem

https://orcid.org/0000-0002-6935-9228

Ayşe Rüveyda Uğur

https://orcid.org/0000-0002-9622-6404

Bahadır Feyzioğlu

https://orcid.org/0000-0002-0991-2132

Mehmet Özdemir

https://orcid.org/0000-0002-9316-771X Mahmut Baykan

https://orcid.org/0000-0002-9954-6040

\begin{abstract}
Öz
Amaç: Parainfluenza virüslerinin (PIV) neden olduğu solunum yolu infeksiyonları bebek ve küçük çocuklarda başlıca morbidite ve hastanede yatış nedenleri arasında yer almaktadır. Bu retrospektif çalışmada alt solunum yolu infeksiyonu nedeniyle takip edilen çocuk hastalarda Parainfluenza virüs infeksiyonlarının sıklığının ve mevsimsel dağılımının araştırılması amaçlanmıştır.

Hastalar ve Yöntem: Ocak 2014 - Aralık 2016 tarihleri arasında çeşitli çocuk kliniklerinde alt solunum yolu infeksiyonu ön tanısıyla ayaktan ve yatarak takip edilen 18 yaş altı hastaların nazofaringeal sürüntü örneklerinde PIV etkeni multipleks polimeraz zincir reaksiyonu (m-PZR) yöntemi ile çalışıldı.

Bulgular: Çalışma sonucunda değerlendirmeye alınan 1983 çocuk hastadan 224'ünde (\%11.3) solunum yolu örneğinde PIV tiplerinden herhangi biri tespit edilmiştir. Alt tiplerin dağılımına bakıldığında etken olarak en sık PIV-3 (\%75) saptanmıştır. Bunu sırasıyla \%15.17 ile PIV-4, \%5.8 ile PIV-1 ve \%4 ile PIV2 takip etmektedir. Hastaların \%75.9 oranında 5 yaş ve altında olduğu belirlendi. Mevsimsel dağılım incelendiğinde, PIV-3 'ün sıklıkla (\%53.6) yaz aylarında, PIV-1 ve PIV-2'nin ise tamamına yakınının sonbahar ve kış aylarında görüldüğü belirlendi.

Sonuç: Hasta grubunda sıklıkla alt solunum yolu infeksiyonu etkeni olan PIV-3 belirlendi. PIV'lerin neden olduğu solunum yolu infeksiyonu etkenlerinin m-PZR yöntemi ile belirlenmesi, klinisyenlere bu viral infeksiyonların tedavi ve korunmasında faydalı olacaktır.
\end{abstract}

Anahtar Kelimeler: Parainfluenza virüs, çocuk hasta, multipleks PZR

\section{Abstract}

Aim: Respiratory infections caused by PIV are related to major morbidity and hospitalization rates in infants and young children. The aim of the present retrospective study is to investigate the rate and seasonal distribution of PIV infections in pediatric patients with lower respiratory tract infections.

Patients and Methods: Nasopharyngeal swab specimens of pediatric in- and outpatients with the diagnosis of lower respiratory infection were collected from various pediatric clinics between January 2014 and December 2016. PIV types 1, 2, 3 and 4 were identified by multiplex real time PCR method. Results: One of the four PIV types was identified in 224 of 1983 nasopharyngeal swab specimens of patients aged less than 18 years $(11.3 \%)$. PIV-3 was the most common agent among the subtypes (75\%) followed by PIV- $4(15.2 \%)$. The rate of PIV-1 and PIV-2 were $5.8 \%$ and $4 \%$, respectively. Of all pediatric patients, $75.9 \%$ were under 5 years of age. When the seasonal distribution was examined, it was determined that PIV-3 was frequently observed in summer $(53.6 \%)$, whereas PIV-1 and PIV-2 were observed in autumn and winter months.

Conclusion: PIV-3 was the most common subtype. Prompt identification of PIV by multiplex real time PCR method would be very helpful for clinicians in the treatment and prevention of the respiratory infections caused by viral pathogens.

Keywords: Parainfluenza virus, pediatric patient, multiplex PCR

\section{GíRiş}

PIV'ler Paramyxoviridae cinsi içerisinde yer alan negatif polariteli tek iplikli RNA virüsleridir. Virüs genetik ve antijenik olarak dört türe ayrılmıştır (1). PIV-4'ün A ve B olmak üzere iki alt türü mevcuttur ve genellikle yetişkinlerde ve çocuklarda hafif üst solunum yolu infeksiyonu ile ilişkilidir. PIV-1, PIV-2 ve PIV-3 bebekler, küçük çocuklar, bağışıklık sistemi baskılanmış kişiler, kronik hastalar ve yaşlılarda ciddi
Atıf yapmak için: Görkem A, Uğur AR, Feyzioğlu B, Özdemir M Baykan M. Çocuk Hastalarda Parainfluenza Nedenli Alt Solunum Yolu Infeksiyonlarının Araştırılması. Selcuk Med J 2020;36(2): 87-90 alt solunum yolu infeksiyonlarının başlıca nedenleri olarak belirlenmiştir (1). PIV soğuk algınlığı ve krup tablosunun en sık sebebi olmaları dışında solunum sinsityal virüsten (RSV) sonra alt solunum yolu infeksiyonları nedeniyle hastaneye başvuruların da ikinci en sık nedeni olduğu bildirilmiştir (2-4). ABD'de her yıl 5 yaşın altındaki çocuklarda yaklaşık beş milyon alt solunum yolu infeksiyonu görülmekte ve bu infeksiyonların üçte birinden PIV'ler izole edilmektedir 


\section{(5).}

Solunum yolu infeksiyon etkeni virüslerin önemli hastane infeksiyonlarına neden olabildiğinin anlaşılması ve viral etkenin hızlı şekilde belirlenmesinin tedaviye yön vereceği bilinci, bu virüslerin tanısının erken dönemde konması gerektiğini göstermiştir (6). Toplumda sık görülen mevsimsel epidemiler yapan solunum yolu virüslerinin hızlı tanı yöntemleri ile belirlenmesi benzer klinik tablodaki hastalara yaklaşımı belirlemede yardımcı olacaktır. m-PZR solunum yolu virüslerini saptamada hızlı, duyarlı ve özgül bir yöntem olarak moleküler yöntemler arasında ilk sırayı almıştır (7).

Bu retrospektif çalışmamızda, hastanemizde alt solunum yolu infeksiyonu nedeniyle takip edilen çocuk hastalarda PIV infeksiyonlarının sıklığının ve mevsimsel dağılımının hızlı ve duyarlı bir yöntem olan m-PZR yöntemiyle belirlenmesi amaçlanmıştır.

\section{HASTALAR VE YÖNTEM}

Bu çalışmada, Ocak 2014 - Aralık 2016 tarihleri arasında çeşitli çocuk kliniklerinde akut solunum yolu infeksiyonu ön tanısıyla ayaktan ve yatarak takip edilen 18 yaş altı hastaların nazofaringeal sürüntü örnek sonuçları retrospektif olarak incelendi. PIV tip 1, 2, 3 ve 4 etkenleri bu süre içerisinde iki farklı ticari kit kullanılarak belirlendi. Haziran 2015 tarihine kadar olan nazofaringeal sürüntü örneklerinde viral etkenlerin belirlenmesi için m-PZR prensibi ile çalışan Seeplex® RV12 ACE Detection (Seegene, Güney Kore) sistemi kullanıldı. Haziran 2015 tarihinden sonra gelen örneklerde ise m-PZR ve DNA mikroarray prensibi ile çalışan CLART® PneumoVir (Clinical Array Technology, Genomica, İspanya) sistemi kullanılarak viral etkenler belirlenmiştir. Bu yöntemle hasta sonuçlarının verilmesi ortalama iki günde tamamlanmıştır.

\section{BULGULAR}

Çalışma sonucunda üç yıllık süre içerisinde çeşitli çocuk kliniklerinden nazofaringeal sürüntü örneği gönderilmiş 1983 çocuk hastadan 224'ünde $(\% 11,3)$ viral etken olarak PIV alt tiplerinden herhangi birinin pozitifliği tespit edilmiştir. PIV pozitifliği saptanmış 224 hastanın 170'inin $(\% 75,9) 5$ yaşın altında çocuklar olduğu belirlenmiştir. Değerlendirmeye alınan bu 224 pozitif örnekte PIV alt tiplerinin dağılımı incelendiğinde etken olarak en sık PIV-3 (\%75) saptanmıştır. Bunu sırasıyla \%15,2 ile PIV-4, \%5,8 ile PIV-1 ve \% 4 ile PIV-2 takip etmektedir (Tablo 1).

PIV-3 pozitifliği tespit edilen 168 çocuktan 131'i
Tablo 1. Parainfluenza virüsleri (PIV) alt tiplerinin dağılımı

\begin{tabular}{lllll}
\hline & PIV-1 & PIV-2 & PIV-3 & PIV-4 \\
\hline Sayı & 13 & 9 & 168 & 34 \\
Yüzde & $\% 5,8$ & $\% 4$ & $\% 75$ & $\% 15,2$ \\
\hline
\end{tabular}

(\%78) 5 yaş altı çocuklardan oluşmaktaydı. Bu hastaların en sık başvuru sebebinin sırasıyla öksürük ve ateş (\% 48,7 ve \% 21,4) olduğu belirlenmiştir.

Pozitiflik saptanan 224 hastada PIV alt tiplerinin mevsimsel özellikleri incelendiğinde aşağıdaki şekilde de belirtildiği gibi PIV-3‘ün $(\% 53,6)$ yaz aylarında, ikinci sıklıkla da sonbahar aylarında dağılım gösterdiğini saptadık. PIV-4'ün yaz sonu ve sonbaharda artış gösterdiğini, yine PIV-1 ve PIV-2 infeksiyonlarının ise tamamına yakınının sonbahar ve kış aylarında görüldüğünü belirledik (Şekil 1).

\section{TARTIŞMA}

PIV soğuk algınlığı ve krup tablosunun en sık sebebi olmaları dışında RSV'den sonra alt solunum yolu infeksiyonları nedeniyle hastaneye başvuruların da ikinci en sık nedeni olduğu bilinmektedir $(4,8,9)$. Çalışmamızda nazofaringeal sürüntü örneklerinde PIV pozitifliği saptanmış çocuk hastaların \%75,9'unun 5 yaşın altında çocuklar olduğu belirlenmiştir. PIV-1, PIV-2 ve PIV-3 özellikle 5 yaşın altındaki çocuklarda ciddi alt solunum yolu infeksiyonlarının başlıca nedenleri olarak bildirilmiştir (1). ABD'de her yıl 5 yaşın altındaki çocuklarda yaklaşık beş milyon alt solunum yolu infeksiyonu görülmekte ve bu

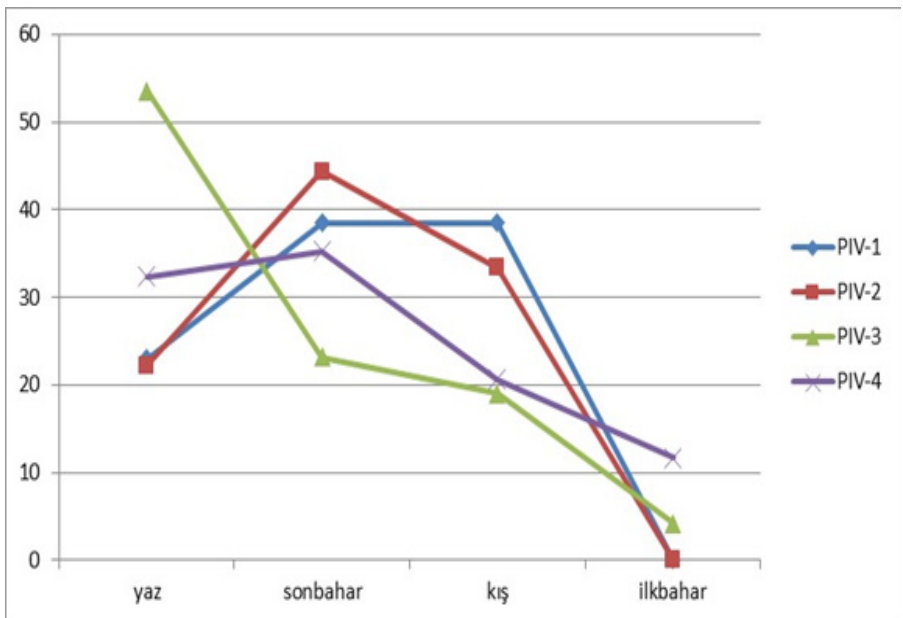

Şekil 1. Parainfluenza virüsleri (PIV) alt tiplerinin yüzde olarak mevsimsel dağılımı 
infeksiyonların üçte birinden PIV'ler izole edilmektedir $(5,10,11)$. PIV-1, PIV-2 ve PIV-3'ün epidemiyolojisi ve klinik belirtileri iyi tanımlanmış olmasına rağmen, mevsimselliği de dahil olmak üzere PIV-4 hakkında çok daha az şey bilinmektedir. PIV-4 çoğunlukla hafif hastalıklarla ilişkilendirilmiştir. Bununla birlikte, bazı durumlarda daha ciddi infeksiyonlara da neden olabileceği gösterilmiştir $(12,13)$. Bizim çalışmamızda da belirlediğimiz gibi PIV-4 infeksiyonları sonbaharda ve kış mevsiminde nispeten daha sık olarak görülebilmektedir (13).

Çalışmamıza dahil edilen çocuk hastaların nazofaringeal sürüntü örneklerinden etken olarak PIV alt tiplerinden herhangi birinin pozitifliği \%11,3 olarak tespit edilmiştir. Alt solunum yolu infeksiyonu tanısıyla takip edilen çocuk hastalarda viral etkenlerin dağılımı ile ilgili yapılan bazı çalışmalarda PIV etkeni görülme oranları benzer şekilde bildirilmiştir $(8,9,14,15)$. PIV infeksiyonlarının tanımlanması ve epidemiyolojisi ile ilgili yapılan çalışmalarda alt tiplerin dağılımına bakıldığında görülme oranı en yüksek olarak PIV3 belirlenmiştir. $(12,16,17)$. Bizim çalışmamızda da benzer şekilde değerlendirmeye alınan çocuk hastalarda PIV alt tiplerinin dağılımı incelendiğinde etken olarak en sık PIV-3 (\%75) saptanmıştır. PIV-3 pozitifliği tespit edilen bu çocukların $\% 78$ oranında 5 yaşın altında oldukları görülmüştür. Bu hastaların en sık başvuru sebebinin sırasıyla öksürük ve ateş (\% 48,7 ve \% 21,4) olduğu belirlenmiştir.

Yenidoğanlar ve küçük çocuklar özellikle PIV3 infeksiyonuna karşı savunmasızdır. Diğer PIV'lerden farklı olarak, PIV-3 infeksiyonlarının \%40'ı yaşamının ilk yılındadır. RSV'den sonra bronşiyolit ve pnömoninin en yaygın sebepleridir. PIV-3'ün neden olduğu alt solunum yolu infeksiyonları nedeniyle her yıl yaklaşık 18.000 bebek ve küçük çocuk Birleşik Devletlerde hastaneye yatırılarak tedavi edilmektedir. $\mathrm{Bu}$ virüs, Kuzey Amerika ve Avrupa'da özellikle immün yetmezlikli ve kronik hastalarda ilkbahar ve yaz salgınlarına neden olur ve bu bölgelerde oldukça endemiktir $(17,18)$. PIV infeksiyonlarının mevsimsel dağılımları incelendiğinde özellikle PIV-3'ün belirgin olarak yaz aylarında salgınlar yaptığı görülmüştür, diğer alt tiplerin ise genel olarak sonbahardan ilkbahara kadar dağılım gösterdiği belirlenmiştir $(5,17,18)$. PIV4 'ün ise yaz sonu ve sonbahar aylarında etken olarak görülme oranları yüksek bulunmuştur $(19,20)$.

Bizim çalışmamızda da PIV alt tiplerinin mevsimsel özelliklerine bakıldığında benzer şekilde PIV-3'ün sıklıkla $(\% 53,6)$ yaz aylarında görüldüğü, PIV4'ün yaz sonunda artmaya başlayıp sonbaharda etken olarak sıklaştığı tespit edilmiştir. PIV-1 ve PIV-2'nin ise tamamına yakınının sonbahar ve kış aylarında dağılım gösterdiği belirlenmiştir. PIV alt tiplerine bağlı infeksiyonların mevsimsel değişiklik göstermelerinin kesin nedenleri bilinmemekle birlikte, iklim koşullarındaki farklılıklar hipotez olarak ileri sürülmüştür $(17,18)$. Bu çalışmada, değerlendirmeye alınan çocuk hasta grubunda sıklıkla alt solunum yolu infeksiyonu etkeni olan PIV-3 belirlenmiştir.

Sonuç olarak, toplumda sık görülen mevsimsel epidemiler yapan PIV infeksiyonlarının belirlenmesi klinisyenlere bu viral infeksiyonların tedavi ve korunmasında yol gösterici olacaktır. Solunum yolu viral etkenlerinin hızlı ve doğru şekilde tanımlanmasında yüksek duyarlılık ve özgüllüğe sahip moleküler teknikler büyük öneme sahiptir.

Çıkar Çatışması: Çalışmada herhangi bir çıkar çatışması yoktur.

Finansal Çıkar Çatışması: Çalışmada herhangi bir finansal çıkar çatışması yoktur.

Yazışma Adresi: Aysun Görkem, Necmettin Erbakan Üniversitesi, Meram Tıp Fakültesi, Mikrobiyoloji Anabilim Dalı, Konya, Türkiye Telefon: 03322236000

E-mail:dr.aysunk@hotmail.com

\section{KAYNAKLAR}

1. Henrickson KJ. Parainfluenza viruses. Clin Microbiol Rev 2003;16:242-64.

2. Carman WF, Mahony JB. The pathogens. J Clin Virol 2007;40:5-10.

3. Counihan ME, Shay DK, Holman RC, et al. Human parainfluenza virus-associated hospitalizations among children less than five years of age in the United States. Pediatr Infect Dis J 2001;20:646-53.

4. Reed G, Jewett PH, Thompson J, et al. Epidemiology and clinical impact of parainfluenza virus infections in otherwise healthy infants and young children $<5$ years old. J Infect Dis 1997;175:807-13.

5. Glezen WP, Frank AL, Taber LH, et al. Parainfluenza virus type 3: Seasonality and risk of infection and reinfection in young children.J Infect Dis 1984,150:851-7.

6. Yolken HY. Laboratory diagnosis of viral infections. In: Galasso GJ, Whitley RJ, Merigan TC, (eds). Practical diagnosis of viral infections. New York: Raven Press, 1993:17-25.

7. Liolios L, Jenney A, Spelman D, et al. Comparison of a multiplex reverse transcription-PCR-enzyme hybridization assay with conventional viral culture and immunofluorescence techniques for the detection of seven viral respiratory pathogens. J Clin Microbiol 2001;39(8):2779-83.

8. Pierangeli A, Gentile M, Di Marco P, et al. Detection and typing by molecular techniques of respiratory viruses in children hospitalized for acute respiratory infection in Rome, Italy. J Med Virol 2007;79:463-8.

9. Carballal G, Videla CM, Espinosa MA, et al. Multicentered study of viral acute lower respiratory infections in children from four cities in Argentina, 1993-1994. J Med Virol 
2001;64:167-74.

10. Denny FW, Clyde WAJ. Acute lower respiratory infections in nonhospitalized children. J Pediatr 1986,108:635-46.

11. Murphy B, Phelan PD, Jack I, et al. Seasonal pattern in childhood viral lower respiratory tract infections in Melbourne. Med J Aust 1980;1:22-4.

12. Aguilar JC, Pérez-Breña MP, García ML, et al. Detection and identification of human parainfluenza viruses $1,2,3$, and 4 in clinical samples of pediatric patients by multiplex reverse transcription-PCR. J Clin Microbiol 2000;38(3):1191-5.

13. Vachon $\mathrm{ML}$, Dionne $\mathrm{N}$, Leblanc É, et al. Human Parainfluenza Type 4 Infections, Canada. Emerg Infect Dis 2006;12(11):1755-8.

14. Cabello $\mathrm{C}$, Manjarrez ME, Olvera R, et al. Frequency of viruses associated with acute respiratory infections in children younger than five years of age at a locality of México City. Mem Inst Oswaldo Cruz 2006;101:21-4.

15. Paranhos-Baccalà $G$, Komurian-Pradel $F$, Richard $N$, et al. Mixed respiratory virus infections. J Clin Virol 2008;43(4):40710.
16. Liu WK, Liu Q, Chen $\mathrm{DH}$, et al. Epidemiology and clinical presentation of the four human parainfluenza virus types. BMC Infectious Diseases 2013;13:28.

17. Fé MM, Monteiro AJ, Moura FE. Parainfluenza virus infections in a tropical city: Clinical and epidemiological aspects. Braz J Infect Dis 2008;12(3):192-7.

18. de Silva LH, and Cloonan MJ. Brief report: Parainfluenza virus type 3 infections: Findings in Sydney and some observations on variations in seasonality world-wide. J Med Virol 1991;35:19-21.

19. Maykowski $P$, Smithgall M, Zachariah $P$, et al. Seasonality and clinical impact of human parainfluenza viruses. Influenza Other Respir Viruses 2018;12(6):706-16.

20. Wu W, Tang YW. Emerging molecular assays for detection and characterization of respiratory viruses. Clin Lab Med 2009;29(4): 673-93. 